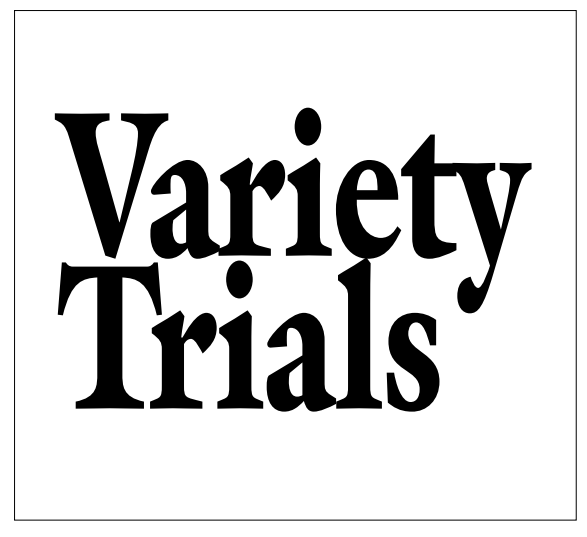

\section{Evaluation of Southern Highbush Blueberry Cultivars for Production in Southwestern Arkansas}

\author{
P. Manjula Carter, ${ }^{1}$ \\ John R. Clark, ${ }^{2}$ and \\ R. Keith Striegler ${ }^{3}$
}

Additional IndeX wORds. Vaccinium corymbosum, heat tolerance, small fruit

Summary. Southern highbush blueberry, a hybrid of northern highbush (Vaccinium corymbosum) and southern-adapted Vaccinium species, has the potential to meet the need for an early-ripening blueberry in the southern U.S. southern highbush cultivars can ripen up to one month earlier than the earliest rabbiteye (Vaccinium ashei) cultivars currently grown in the southern U.S. However, chilling requirement and cold-hardiness are cultivar-dependent

The authors thank Jack F. Young for data collection during the first 3 years of the trial and Michael J. McCorkle for assistance in plot maintenance.

${ }^{1}$ Research specialist III, University of Arkansas, Southwest Research and Extension Center, 362 Hwy. 174 N., Hope, AR 71801 .

${ }^{2}$ Professor, University of Arkansas, Fayetteville, Department of Horticulture, 316 Plant Science Building, AR 72701-1201.

${ }^{3}$ Extension fruit specialist and associate professor. for southern highbush and cultivar testing has been necessary to determine the cultivars best adapted to specific hardiness zones. In a 4-year study at Hope, Ark. (hardiness zone $7 \mathrm{~b}$ ), several southern highbush cultivars were evaluated for productivity, fruit quality and reliability of cropping. Yields were based on 1089 plants/acre (2690 plants/ha) for southern highbush cultivars and 605 plants/acre (1494 plants/ha) for rabbiteye cultivars. 'Ozarkblue' and 'Legacy' showed the most adaptability at this location, yielding on average $11,013 \mathrm{lb} /$ acre $\left(12,309 \mathrm{~kg} \cdot \mathrm{ha}^{-1}\right)$ and $10,328 \mathrm{lb} /$ acre $\left(11,543 \mathrm{~kg} \cdot \mathrm{ha}^{-1}\right)$ respectively, compared to $4882 \mathrm{lb} /$ acre $\left(5456 \mathrm{~kg} \cdot \mathrm{ha}^{-1}\right)$ for 'Premier' (rabbiteye) over 4 years. 'Ozarkblue' and 'Legacy' also rated well for plant vigor and fruit quality. We would recommend 'Ozarkblue' and 'Legacy' for commercial planting in southwest Arkansas and believe these cultivars have production potential for other areas of the southern U.S. that have similar hardiness zones and soil type to southwest Arkansas.

$\mathrm{B}$ lueberry production in North America has ex panded rapidly in recent years. In 1999, Arkansas produced 510 tons (463 t) of blueberries with a value of $\$ 1,212,000$, and $91 \%$ of production was utilized in the fresh market (USDA, 2001a). Of the types of blueberry cultivated in the U.S., southern highbush has shown the most rapid percentage increase in acreage, and is predicted to account for $10 \%$ of the total U.S. production by 2008 (Pittman et al., 1998).

Commercial production of blueberries in Arkansas began in northwest Arkansas (hardiness zone 6) in the 1970s. Then production consisted of northern highbush cultivars including 'Bluecrop' and 'Blueray'. However, these northern highbush cultivars were ill-adapted to the hot climate of southwest Arkansas, where southern-adapted rabbiteye cultivars such as 'Tifblue' and 'Woodard' were found to flourish (Moore, 1976). Despite adaptation to the south (hardiness zones 7-8), rabbiteye cultivars are susceptible during bloom to late spring freezes experienced in southwest Arkansas, and they tend to ripen later in the season than highbush. The subsequent need for an early-ripening blueberry has been successfully met by the southern highbush blueberry, a hybrid of northern highbush and one or more southernadapted types.

There are currently five states involved in breeding southern highbush (Moore, 1993): Arkansas, Florida, Georgia, Mississippi and North Carolina. Research stations involved with the breeding program in these states are located in hardiness zones 7 and 8 . The research stations at Hope, Ark., Tifton, Ga., Poplarville, Miss., and Raleigh, N.C., share a similar climate: Mean annual temperatures and precipitation at these stations range from 61 to $66^{\circ} \mathrm{F}\left(16\right.$ to $\left.19^{\circ} \mathrm{C}\right)$ and 50 to 60 inches (120 to $144 \mathrm{~cm}$ ) respectively (Owenby and Ezell, 1992). Annual cooling degree days below $65^{\circ} \mathrm{F}$ are 2400 at Poplarville, 2300 at Tifton, 2000 at Hope and 1500 at Raleigh (Owenby and Ezell, 1992). In Arkansas, December and January are the coldest months with average monthly lows ranging from 28 to $36^{\circ} \mathrm{F}$ ( -2 to $\left.2{ }^{\circ} \mathrm{C}\right)$. At Hope, there is a $90 \%$ probability of a light freeze $\left[32^{\circ} \mathrm{F}\left(0^{\circ} \mathrm{C}\right)\right]$ occurring after 16 Mar. (Koss et al., 1988) when most southern highbush are at full bloom. Similar late spring freezes are also experienced in Georgia, Mississippi, and North Carolina (Koss et al., 1988). Consequently breeding and testing of southern highbush cultivars at the University of Arkansas has focused on the need for improved bud hardiness and fruit quality in this type of blueberry. The percentage of evergreen blueberry ( $V$. darrowi) in the parentage of southern highbush cultivars has a strong influence on bud hardiness (Clark et al., 1996) and those having less than 25\% evergreen blueberry in their parentage tend to be hardier. For example, 'Ozarkblue' with $13 \%$ evergreen blueberry has demonstrated reliable fruiting in both northwest and southwest Arkansas (Clark et al., 1996). However, southern highbush is suited to traditional rabbiteye areas and is generally not productive in areas of Arkansas where northern highbush is grown. Early-ripening southern highbush cultivars provide growers in southwest Arkansas, and other states with similar climatic conditions, with an alternative to rabbiteye and an economic advantage for fresh market sales. Due to the similarities in growing conditions, southern highbush cultivars developed in Mississippi, Georgia, and North Carolina were included in our evaluation. The purpose of this study was to 
Table 1. Budswell and bloom dates for southern highbush cultivars, 1997-2000 at the Southwest Research and Extension Center, Hope, Ark.

\begin{tabular}{|c|c|c|c|c|c|c|c|c|c|c|c|c|c|c|c|}
\hline \multirow[b]{2}{*}{ Cultivar } & \multicolumn{5}{|c|}{ Budswell (day of the year) } & \multicolumn{5}{|c|}{$10 \%$ Bloom (day of the year) } & \multicolumn{5}{|c|}{$50 \%$ Bloom (day of the year) } \\
\hline & 1997 & 1998 & 1999 & 2000 & Mean & 1997 & 1998 & 1999 & 2000 & Mean & 1997 & 1998 & 1999 & 2000 & Mean \\
\hline Georgiagem & $2 c^{z}$ & $10 \mathrm{c}$ & $30 \mathrm{bc}$ & $30 \mathrm{c}$ & 18 & $67 \mathrm{~b}$ & $67 \mathrm{~cd}$ & $48 \mathrm{c}$ & $62 d$ & 61 & $77 \mathrm{c}$ & $88 \mathrm{a}$ & $62 \mathrm{~b}$ & $73 \mathrm{bc}$ & 75 \\
\hline O’Neal & $2 \mathrm{c}$ & $3 \mathrm{~d}$ & $21 \mathrm{~d}$ & $25 \mathrm{c}$ & 13 & $57 \mathrm{c}$ & $43 \mathrm{e}$ & $37 \mathrm{~d}$ & $59 \mathrm{~d}$ & 49 & $72 \mathrm{~cd}$ & $62 \mathrm{c}$ & $45 \mathrm{c}$ & $77 \mathrm{~b}$ & 64 \\
\hline Ozarkblue & $60 \mathrm{a}$ & $41 \mathrm{a}$ & $52 \mathrm{a}$ & 66 a & 55 & 91 a & 90 a & 89 a & $87 \mathrm{a}$ & 89 & $97 \mathrm{a}$ & $94 \mathrm{a}$ & 98 a & $94 \mathrm{a}$ & 96 \\
\hline Premier & $3 \mathrm{c}$ & $11 \mathrm{bc}$ & $26 \mathrm{~cd}$ & $25 \mathrm{c}$ & 16 & $69 \mathrm{~b}$ & $83 \mathrm{~b}$ & $58 \mathrm{~b}$ & $67 c$ & 69 & $73 \mathrm{~cd}$ & $89 a$ & $63 \mathrm{~b}$ & $76 \mathrm{~b}$ & 75 \\
\hline
\end{tabular}

${ }^{\mathrm{z}}$ Within a column, numbers followed by the same letter(s) are not significantly different as determined by least significant difference $(P \leq 0.05)$.

$\mathrm{y}_{\text {LSD }}$ for comparing across years within a cultivar $(P \leq 0.05)$.

evaluate these southern highbush cultivars so that recommendations can be made of cultivar adaptation to the region.

\section{Materials and methods}

The blueberry planting was established in 1994 at the University of Arkansas Southwest Research and Extension Center, Hope (lat. $33^{\circ} 43^{\prime} 00^{\prime} \mathrm{N}$, long. $93^{\circ} 33^{\prime} 00^{\prime} \mathrm{W}$ ). The soil type was a Bowie fine sandy loam (USDA, 1979). Initially the trial contained the cultivars Bladen, Blueridge, Cape Fear, Cooper, Georgiagem, Gulf Coast, Legacy, O'Neal, Ozarkblue, and Summit. 'Brightwell' and 'Premier' (rabbiteyes) were also included as standard adapted cultivars for comparison. These cultivars represented a range of bloom characteristics and chilling re- quirements. 'Cooper' and 'Gulfcoast' were developed at Poplarville, Miss., 'Brightwell' and 'Georgiagem' at Tifton, Ga., 'Ozarkblue' at Fayetteville, Ark., and the remaining cultivars except 'Legacy' were developed at Raleigh, N.C. 'Legacy' was selected in New Jersey and recommended for planting in North Carolina and Arkansas (USDA, 2001b). Following 2 years of data collection, 'Bladen', 'Blueridge', 'Cape Fear', 'Cooper', and 'Gulfcoast' were removed from the trial due to low yield and poor vigor. Since only one rabbiteye was needed for subsequent comparisons, 'Brightwell' was also removed. The experimental design was a randomized complete block with six replications and two plants per plot. Only one plant chosen randomly from each plot was used in data collection. The plants were grown on $2-\mathrm{ft}(61-\mathrm{cm})$ high beds. Peatmoss [ 1 gal $(3.8 \mathrm{~L})]$ was added to the planting hole and plants were mulched annually with pine straw to a depth of 6 inches $(15 \mathrm{~cm})$. Fertilizer nitrogen was applied annually at a rate of $120 \mathrm{lb} /$ acre $\left(134 \mathrm{~kg} \cdot \mathrm{ha}^{-1}\right)$ and soil $\mathrm{pH}$ was naturally about 5.2 . Data were collected from 1997-2000 when the plants were 4 to 7 years of age. Data collected included dates of budswell (stage 2 buds, Spiers, 1978), 10\% and $50 \%$ bloom, total yield per plant and average berry weight. Date of first harvest varied with cultivar. A bush was considered ready to harvest when 25 or more ripe berries were present. Ripe berries were then harvested twice per week on average until the bush was bare. Yield per acre was calculated by

Table 2. Yield and berry weight (1997-2000) of southern highbush blueberry cultivars established in 1994 at the Southwest Research and Extension Center, Hope, Ark.

\begin{tabular}{|c|c|c|c|c|c|}
\hline \multirow[b]{2}{*}{ Cultivar } & \multicolumn{5}{|c|}{ Year } \\
\hline & 1997 & 1998 & 1999 & 2000 & Mean \\
\hline \multicolumn{6}{|l|}{ Yield $^{\mathrm{x}}(\mathrm{lb} / \text { acre })^{\mathrm{w}}$} \\
\hline Legacy & $7,700 \mathrm{~b}$ & $14,000 \mathrm{a}$ & $10,700 \mathrm{a}$ & $7,900 \mathrm{ab}$ & 10,300 \\
\hline O’Neal & $3,800 \mathrm{bc}$ & $4,900 \mathrm{~cd}$ & $1,700 \mathrm{~b}$ & $1,100 \mathrm{~b}$ & 3,200 \\
\hline Ozarkblue & $15,400 \mathrm{a}$ & $13,400 \mathrm{ab}$ & $5,100 \mathrm{~b}$ & $6,100 \mathrm{ab}$ & 11,000 \\
\hline $\mathrm{LSD}=3174^{\mathrm{y}}$ & & & & & \\
\hline \multicolumn{6}{|c|}{ Single berry weight $(\mathrm{g})^{\mathrm{w}}$} \\
\hline Georgiagem & $1.1 \mathrm{c}$ & $1.0 \mathrm{c}$ & $0.9 \mathrm{c}$ & $1.0 \mathrm{c}$ & 0.9 \\
\hline Legacy & $0.9 \mathrm{~d}$ & $1.3 \mathrm{~b}$ & $1.0 \mathrm{c}$ & $1.4 \mathrm{ab}$ & 1.1 \\
\hline O’Neal & $1.2 \mathrm{bc}$ & $1.5 \mathrm{a}$ & $1.4 \mathrm{~b}$ & $1.5 \mathrm{a}$ & 1.4 \\
\hline
\end{tabular}

${ }^{2}$ Within a column, numbers followed by the same letter(s) are not significantly different as determined by least significant difference $(P \leq 0.05)$. $\mathrm{y}_{\text {LSD }}$ for comparing across years within a cultivar $(P \leq 0.05)$.

'Yields are based on plant densities of 1089 and 605 plants/acre (2690 and 1494 plants/ha) for southern highbush and rabbiteye respectively.

w $1 \mathrm{lb} /$ acre $=1.12 \mathrm{~kg} \cdot \mathrm{ha}^{-1}, 1.0 \mathrm{~g}=0.035 \mathrm{oz}$. 
Table 3. Plant vigor, plant health, berry stem scar, and berry flavor ratings for southern highbush blueberry cultivars, averaged for 1997-98 at the Southwest Research and Extension Center, Hope, Ark. Ratings are based on a scale of 1 to 10 where 1 = poor and $10=$ exceptional.

\begin{tabular}{lcccc}
\hline Cultivar & $\begin{array}{c}\text { Plant } \\
\text { vigor }\end{array}$ & $\begin{array}{c}\text { Plant } \\
\text { health }\end{array}$ & $\begin{array}{c}\text { Berry } \\
\text { stem scar }\end{array}$ & $\begin{array}{c}\text { Berry } \\
\text { flavor }\end{array}$ \\
\hline Georgiagem & $5.3 \mathrm{~d}^{\mathrm{z}}$ & $6.2 \mathrm{c}$ & $7.0 \mathrm{~d}$ & $8.3 \mathrm{~b}$ \\
Legacy & $7.4 \mathrm{~b}$ & $7.7 \mathrm{~b}$ & $7.8 \mathrm{c}$ & $7.6 \mathrm{c}$ \\
O'Neal & $5.6 \mathrm{~d}$ & $6.3 \mathrm{c}$ & $9.1 \mathrm{a}$ & $8.4 \mathrm{~b}$ \\
Ozarkblue & $7.3 \mathrm{~b}$ & $8.1 \mathrm{a}$ & $8.0 \mathrm{c}$ & $7.6 \mathrm{c}$ \\
Premier & $8.5 \mathrm{a}$ & $8.4 \mathrm{a}$ & $8.5 \mathrm{~b}$ & $7.3 \mathrm{c}$ \\
Summit & $6.7 \mathrm{c}$ & $7.2 \mathrm{~b}$ & $8.3 \mathrm{~b}$ & $9.0 \mathrm{a}$ \\
\hline
\end{tabular}

${ }^{2}$ Within a column, numbers followed by the same letter(s) are not significantly different as determined by least significant difference $(P \leq 0.05)$

Table 4. Color and firmness ratings for fruit from southern highbush blueberry cultivars, 1997-98 at the Southwest Research and Extension Center, Hope, Ark. Ratings are based on a 1 to 10 scale where $1=$ poor and $10=$ exceptional.

\begin{tabular}{|c|c|c|c|c|}
\hline \multirow[b]{2}{*}{ Cultivar } & \multicolumn{2}{|c|}{ Color } & \multicolumn{2}{|c|}{ Firmness } \\
\hline & 1997 & 1998 & 1997 & 1998 \\
\hline Georgiagem & $7.8 \mathrm{a}^{\mathrm{z}}$ & $8.3 \mathrm{~b}$ & $7.0 \mathrm{~d}$ & $7.2 \mathrm{c}$ \\
\hline Legacy & $7.7 \mathrm{a}$ & $8.0 \mathrm{~b}$ & $7.3 \mathrm{~cd}$ & $8.0 \mathrm{~b}$ \\
\hline O’Neal & $7.0 \mathrm{~b}$ & $7.0 \mathrm{c}$ & $9.0 \mathrm{a}$ & $9.0 \mathrm{a}$ \\
\hline Ozarkblue & $8.0 \mathrm{a}$ & $8.0 \mathrm{~b}$ & $8.3 \mathrm{~b}$ & $8.0 \mathrm{~b}$ \\
\hline Premier & $8.0 \mathrm{a}$ & $8.3 \mathrm{~b}$ & $7.7 \mathrm{c}$ & $8.0 \mathrm{~b}$ \\
\hline Summit & $8.0 \mathrm{a}$ & $8.8 \mathrm{a}$ & $8.0 \mathrm{~b}$ & $8.0 \mathrm{~b}$ \\
\hline $\operatorname{LSD}^{y}$ & \multicolumn{2}{|c|}{0.4} & \multicolumn{2}{|c|}{0.4} \\
\hline
\end{tabular}

${ }^{2}$ Within a column, numbers followed by the same letter(s) are not significantly different as determined by least significant difference $(P \leq 0.05)$.

$\mathrm{y}_{\mathrm{LSD}}$ for comparing years within a cultivar.

multiplying plant yield by plant density per acre (1089 and 605 plants/ acre for southern highbush and rabbiteye respectively). Since each data plant was effectively an end plant in the row, our yields may be greater than those typical of a field situation. In 1997 and 1998 cultivars were also rated for vigor and health, and berries were rated at full maturity for color, firmness, flavor and stem scar on a scale of 1 to 10 where 1 was poor, 5 was average, 8 very good and 10 exceptional. Berry ratings were conducted in the field by John Clark on freshly harvested fruit and were based on 5 to 10 berries per replication. The major component of berry color was the degree of bloom on the berry, and berries with a light color (high bloom) were given the highest color rating. Firmness was based on the feel of the berries when squeezed between the fingers, with highest ratings for those that resisted this force. Flavor was rated based on a combination of flavor components detected in the taste including sweetness, acidity, and overall expression of other flavors. The highest rat- ings were given for berries with a good balance of acidity and sweetness that were not bland in flavor. In rating stem scar, a small, dry scar was preferable and rated highly, while a large wet scar was undesirable and rated poorly. Data were analyzed as a split-plot in time using SAS and means were separated by least significant difference (LSD) ( $P$ $\leq 0.05)$ (Gomez and Gomez, 1984). Correlation between fruit quality factors was also investigated using SAS correlation analysis.

\section{Results and discussion}

Although the first crop was produced in 1996, frost damage in this year reduced yields significantly for nearly all cultivars as compared to following years. Therefore, only data from 1997-2000 were analyzed and presented. 'Bladen', 'Blueridge', 'Cape Fear', 'Cooper', and 'Gulf Coast' yielded significantly less than the rabbiteyes, and rated lower for health and vigor in both 1997 and 1998 (data not shown). These cultivars were subsequently discarded due to lack of adaptation at this location. A difference in the annual number of cooling degree days between Arkansas and the states where these cultivars were developed may have contributed to their poor performance.

The interaction between year and cultivar was significant for budswell, $10 \%$ and $50 \%$ bloom, indicating that annual weather patterns greatly influenced all stages of bloom. Due to its late blooming character, 'Ozarkblue' was not as susceptible to freeze or frost damage as the other cultivars (Table 1). Despite a $20 \%$ yield reduction in 1996 due to frost damage compared to following years, 'Ozarkblue' still had the largest crop of all cultivars that year while the early-blooming cultivars Gulfcoast and O'Neal produced no crop (data not shown). 'Georgiagem', 'Legacy', and in some years 'O'Neal', were similar in their bloom characteristics and tended to bloom earlier than 'Premier'. 'Summit' reached budswell later than all the other cultivars except 'Ozarkblue', but was comparable to 'Premier' and 'Georgiagem' for $50 \%$ bloom (Table 1). All the southern highbush cultivars ripened before 'Premier' reaching their peak yields in mid to late May, whereas 'Premier' peaked in mid-June.

Yields varied annually and the year by cultivar interaction was significant (Table 2). Yields for all cultivars were reduced in 1999 compared to 1998. This may be attributed to the mild winter in 1998-99 which resulted in a lack of adequate chilling and delayed budbreak. For most years, chilling hours [hours below $44.6^{\circ} \mathrm{F}(7$ $\left.{ }^{\circ} \mathrm{C}\right)$ ] accumulated were 700 to $800 \mathrm{~h}$. However, in 1999 plants experienced only about $600 \mathrm{~h}$ of chilling. Yield loss in 1999 was greatest for 'Ozarkblue' since this cultivar has a chilling requirement of 800 to 1000 h (Clark and Moore, 1996). Yields in 2000 were lower than in previous years for all cultivars, except for 'Premier'. Despite yearly fluctuations, 'Ozarkblue' and 'Legacy' had the highest yields overall producing an average of 11,013 $\mathrm{lb} /$ acre and 10,328 $\mathrm{lb}$ /acre respectively, more than double the average yield for 'Premier'.

Berry weight varied from year to year but was similar for all cultivars except 'Legacy' and 'Georgiagem' which tended to have smaller berries (Table 2). Yields of 'Legacy' were high despite a small berry size due to a larger number of berries. 'Ozarkblue' and 
'Summit' had the most consistent berry weight across years, both averaging $1.4 \mathrm{~g}$ compared to $1.3 \mathrm{~g}$ for 'Premier'.

Subjective ratings of plant and berry characteristics in 1997 and 1998 showed that plant vigor and health, stem scar and flavor were consistent across years (Table 3 ), while there was an interaction between year and cultivar for fruit color and firmness (Table 4). 'Premier', 'Legacy' and 'Ozarkblue' had good health and vigor, which is reflected in the yields for these cultivars. 'Georgiagem' and 'O'Neal' were the least vigorous. 'Summit' rated highest for flavor followed by 'O'Neal' and 'Georgiagem'. The flavor ratings for 'Ozarkblue' and 'Legacy' were similar to 'Premier'. There was little difference in berry color rating among the varieties, although 'O'Neal' rated lower than the others in both years due to its darker skin color (Table 4). 'O'Neal' had the firmest berries in both years while berries of 'Legacy', 'Ozarkblue', and 'Summit' were similar to those of 'Premier' in firmness. 'Legacy' was significantly firmer in 1998 than 1997, again indicating the possible influence of annual weather patterns on fruit quality. 'O'Neal' had the highest rating for stem scar. 'Summit', 'Premier', 'Ozarkblue', and 'Legacy' also rated high for stem scar. Increasing firmness was associated with a smaller picking scar $\left(r^{2}=0.85\right)$. Good firmness and small picking scar are desirable traits for shipping and fresh market. Overall, 'Ozarkblue' rated better for fruit quality variables (stem scar, flavor, color, firmness) compared to 'Premier'. These results suggest that 'Ozarkblue' and 'Legacy' are adapted to the climate of southwest Arkansas and can be recommended for commercial planting.

\section{Literature cited}

Clark, J.R., R. Bourne, and E. Gbur. 1996. Flower bud hardiness and shoot hardiness of southern highbush blueberry cultivars. Fruit Var. J. 50:98-104.

Clark, J.R. and J.N. Moore. 1996.
'Ozarkblue' southern highbush blueberry. HortScience 31:1043-1045.

Gomez, K.A. and A.A. Gomez. 1984 Comparison between treatment means, $\mathrm{p}$. 188-207. In: Statistical procedures for agricultural research. John Wiley \& Sons, New York.

Koss, W.J., J.R. Owenby, P.M. Steurer, and D.S. Ezell. 1988. Freeze/frost data. Climatography of the U.S. No. 20, Suppl. 1. U.S. Dept. of Commerce, Natl. Oceanic Atmos. Admin., Natl. Climatic Data Ctr., Asheville, N.C.

Owenby, J.R. and D.S. Ezell. 1992. Climatography of the U.S. No. 81: Monthly station normals of temperature, precipitation, and heating and cooling degree days, 1961-90. U.S. Dept. of Commerce, Natl. Oceanic and Atmos. Admin., Natl. Climatic Data Ctr., Asheville, N.C.

Moore, J.N. 1993. Blueberry cultivars of North America. HortTechnology 3:370 374.

Moore, J.N. 1976. Adaptation and production of blueberries in Arkansas. Ark. Agr. Expt. Sta. Bul. 804.

Spiers, J.M. 1978. Effect of stage of bud development on cold injury in rabbiteye blueberry. J. Amer. Soc. Hort. Sci. 103:452-455.

Pittman, P.O., J.H. Braswell, and J.M. Spiers. 1998. Survey of major small fruit crops grown in the United States. Proc. VIII North Amer. Blueberry Res. and Ext. Workers Conf., Wilmington, N.C., 27-29 May. 1998. p. 245-254.

U.S. Department of Agriculture. 1979. Hoelscher, J.E., and Laurent, G.D. (eds.). Soil survey of Hempstead county Arkansas. U.S. Dept. Agr. Soil Conservation Serv. in cooperation with Ark. Agr. Expt. Sta.

U.S. Department of Agriculture. 200la. Crop production (PCP-BB). USDA, National Agricultural Statistics Service. 19 Dec. 2001. <http://www.usda.mannlib. cornell.edu/reports/nassr/field/pcp-bb/>

U.S. Department of Agriculture. 2001b. Notice of release of Legacy highbush blueberry. USDA and New Jersey Agr. Expt. Sta. 19 Dec. 2001. <http://www.barc. usda.gov/psi/fl/ehl-leg.html>
Performance of

15 Pecan

Cultivars and

Selections over

20 Years in

Southern Georgia

\author{
Patrick J. Conner ${ }^{1}$ and \\ Ray E. Worley
}

AdDitional INDEX wORds. yield, quality, variety, alternate bearing, trial, Carya illinoinensis

Summary. Fifteen pecan (Carya illinoinensis) genotypes were evaluated over a period of 20 years in a test orchard located near Tifton, Ga. Genotypes tested included seedling selections ('Candy', 'Maramec', 'Melrose', 'Moreland', 'Sumner', and 'Western Schley'), USDA releases ('Creek', 'Kanza', 'Kiowa', and 'Pawnee'), and USDA selections (USDA 41-19-20, USDA 53-11-139, USDA 53-9-1, USDA 57-7-22, and USDA 64-11-17). Actual yields were measured for each tree in the test throughout the test period and the alternate bearing intensity (I) of each cultivar was calculated. Average annual nut production in years 1 to 10 ranged from $19 \mathrm{lb}(8.6 \mathrm{~kg})$ in the precocious cultivar 'Candy' to $6 \mathrm{lb}(2.7 \mathrm{~kg})$ in the nonprecocious cultivar 'Melrose'. Although a wide variation was seen in the average yield of clones in years 11 to 20, differences were not significant. A subsample of nuts was taken for each tree annually and percent kernel, nuts / $\mathrm{lb}$, specific gravity, and nut volume were determined. Significant differences were found between clones for each of these traits. Most clones were not acceptable for commercial use in Georgia due to small nut size, poor kernel quality, or excessive alternate bearing. Recommended clones include: 'Pawnee', which produced large nuts of excellent quality with an early harvest date, 'Sumner', which produced large nuts of moderate quality with a late harvest date, and 'Kiowa', a precocious bearer of large, good-quality nuts.

Department of Horticulture, University of Georgia Coastal Plain Experiment Station, 4604 Research Way, Tifton, GA 31793

${ }^{1}$ To whom correspondence should be addressed; email pconner@tifton.cpes.peachnet.edu. 